\title{
LONG-TERM EFFECT OF ONE-TIME NUTRITIONAL EDUCATION IN SCHOOL ON NUTRITIONAL KNOWLEDGE OF EARLY SCHOOL-AGED CHILDREN
}

\author{
Aleksandra Chojnackal, Magdalena Górnickal, Kacper Szewczyk ${ }^{l}$
}

${ }^{1}$ Warsaw University of Life Sciences (WULS), Institute of Human Nutrition Sciences, Department of Human Nutrition, Warsaw, Poland

\begin{abstract}
Background. In the group of school-aged children nutritional education (NE) enables an early development of healthy eating habits, which can be transferred to the adult life.

Objective. The aim of the study was to assess the long-term effect of a one-time nutritional education, including also culinary workshops, on the level of nutritional knowledge (NK) of early school-aged children as well as to analyse the nutritional content of the children's books.

Material and methods. The study was conducted among second- and third-grade pupils from a primary school in Warsaw ( $\mathrm{n}=76$ ). The level of NK was determined using the same, self-administrated questionnaire at each of the three stages of the study.

Results. The level of NK was assumed as very good in $47 \%$ of respondents before the education, in $91 \%$ immediately after the education, and in $74 \%$ six months after it. Out of all 23.0 points (max.) on average 18.1 points were obtained at the first stage, 21.1 points at the second stage and 19.7 points at the third stage $(\mathrm{p}<0.001)$. Immediately after the NE and six months after it the level of NK increased significantly (comparing to the first stage) especially on these topics: the daily water requirements and the recommendations on physical activity $(\mathrm{p}<0.001$ for both questions).

Conclusions. The results of the study confirmed the effectiveness of a one-time nutritional education on the level of nutritional knowledge. Moreover, results show that in the research group nutritional knowledge about importance of physical activity, adequate nutrition, eating varicoloured vegetables and fruits, screen time limits and distinguishing between healthy and unhealthy products was satisfactory, even at the baseline, but in the main source of fats in a diet, the role of milk products, the effect of having too little water in a diet and the sugar content in food children's knowledge was not enough.
\end{abstract}

Key words: nutritional education, nutritional knowledge, school-based programs, children, primary schools

\section{STRESZCZENIE}

Wprowadzenie. W grupie dzieci w wieku szkolnym edukacja żywieniowa (EŻ) pozwala wcześnie kształtować prawidłowe nawyki żywieniowe, które mogą być przeniesione w dorosłe życie.

Cel badań. Celem pracy była ocena długoterminowego wpływu jednorazowej edukacji żywieniowej (obejmującej również warsztaty kulinarne) na poziom wiedzy żywieniowej (WŻ) dzieci w wieku wczesnoszkolnym oraz analiza treści żywieniowych zawartych w podręcznikach uczniów.

Materiał i metod. Badanie przeprowadzono w grupie uczniów z klas II i III szkoły podstawowej w Warszawie (n=76). Do zbadania poziomu wiedzy żywieniowej na każdym z etapów badania wykorzystano ten sam, autorski kwestionariusz ankiety.

Wyniki. Bardzo dobry poziom wiedzy żywieniowej stwierdzono u 47\% badanych na pierwszym etapie badania, u $91 \%$ badanych bezpośrednio po edukacji i u $74 \%$ badanych po sześciu miesiącach. Na 23,0 możliwe do uzyskania punkty respondenci uzyskali średnio: 18,1 punktów na etapie 1,21,1 na etapie 2 i 19,7 na etapie 3, co świadczy o korzystnym wpływie jednorazowej edukacji żywieniowej na wiedzę żywieniową uczniów ( $<<0,001)$. Bezpośrednio po edukacji oraz sześć miesięcy później poziom WŻ znacząco wzrósł (w porównaniu do etapu pierwszego), szczególnie w zakresie: dziennego zapotrzebowania na wodę oraz zaleceń dotyczących aktywności fizycznej ( $<<0,001$ dla obu pytań).

Wnioski. Otrzymane wyniki potwierdzają korzystny wpływ edukacji żywieniowej na wiedzę żywieniową uczniów. Ponadto w grupie badanej wiedza żywieniowa w zakresie: znaczenia aktywności fizycznej, prawidłowego żywienia,

Corresponding author: Magdalena Górnicka, Szkoła Główna Gospodarstwa Wiejskiego w Warszawie, Instytut Nauk o Żywieniu Człowieka, Katedra Żywienia Człowieka, ul. Nowoursynowska 159C, 02-776 Warszawa, Polska, tel. +48 225937123 , e-mail: magdalena_gornicka@sggw.edu.pl

(C) Copyright by the National Institute of Public Health - National Institute of Hygiene 
spożywania różnych warzyw i owoców, ograniczeń czasu spędzanego przed ekranem, a także rozróżniania produktów zalecanych i niezalecanych była zadowalająca, zaś jeżeli chodzi o zagadnienia takie jak: zalecane źródła tłuszczu w diecie, rola produktów mlecznych, niekorzystne efekty picia zbyt malej ilości wody oraz zawartość cukru w produktach, wiedza uczniów okazała się niewystarczająca.

Słowa kluczowe: edukacja żywieniowa, wiedza żywieniowa, szkolne programy, dzieci, szkoły podstawowe

\section{INTRODUCTION}

Nowadays, a high prevalence of childhood overweight and obesity is observed both in developed and developing countries [3, 24, 27]. According to the WHO, over 340 million children and adolescents aged $5-19$, were obese or overweight in 2016, worldwide [37]. Among Polish children aged 8, the problem of overweight and obesity occurred in almost $1 / 3$ of children $(31 \%)-32 \%$ of the surveyed boys and $29 \%$ of the surveyed girls based on WHO criteria [4, 7]. What is alarming, childhood obesity increases the chance of being obese in later childhood and leads to adulthood obesity as well $[6,11]$. It has also been proven that overweight and obesity are one of the major risk factors for other noncommunicable, dietrelated diseases such as hypertension, lipid disorders and type 2 diabetes [13, 14]. Although many of them appear mainly in adult life, they are associated with adverse nutritional behaviours, already present in childhood (such as insufficient consumption of vegetables and fruits, and excessive consumption of sweets and sweetened drinks) as well as lifestyle risk factors (such as sedentary lifestyle and insufficient physical activity) [20]. Nowadays, in the wake of the COVID-19 pandemic, adverse health behaviours have sharply increased, which resulted in weight gaining $[1,29]$. Moreover, studies show that school-aged children are a nutritionally vulnerable group because of high nutritional requirements, intensified growth and development and high susceptibility to negative advertising, fashion and environmental patterns, created by their peers $[5,35,36]$.

Therefore, there is no doubt that due to the high prevalence of adverse health behaviours among children and possible future consequences, it is important to implement evidence-based policies, such as nutritional education in schools, which will promote healthier dietary choices. Previous studies show that the increasing consumption of unhealthy foods in children is due to improper parents' attitudes toward unhealthy foods, social acceptance of eating unhealthy foods as well as due to the lack of knowledge and misunderstanding of the importance of healthy eating habits $[16,17,28]$. Moreover, the consequences of frequent unhealthy eating are delayed in time and as an effect seems not to be well-understood by children [16]. Based on previous studies' results, nutritional education has been shown to be effective in increasing knowledge and appropriate dietary choices $[8,34,35]$. The efficacy of nutritional education is as high as the design and use of theories as well as a selection of educational methods which are more adapted to a given group $[2,17]$. Moreover, it was stated that for nutritional education to be the most effective should last five or more months, should have support from school leadership and policymakers, and should involve not only children but also their parents $[2,22,32]$.

Unfortunately, in most countries, health education (and as a component - nutritional education) in schools is not a priority. It rather remains on the periphery of the implemented program, has a low rank and is definitely underestimated by people, who create education and health policy $[16,40]$. In Poland, nongovernmental organisations, such as societies and foundations, are the ones which conduct nutritional education, which, as part of their activities include nutritional workshops with school children in the form of talks, discussions, games and cooking workshops [40, 41]. There are also governmental nutritional education programs, such as the I know, what I eat (Wiem co jem) campaign - a campaign of the Warsaw local government and the Program for schools (Program dla szkót) - an EU program, whose aim is to supply children with fruits and vegetables, milk and dairy products in schools. On the one hand, there are no available studies, which confirm the effectiveness of nutritional education in the group of early school children $[15,25]$. On the other hand, interventional nutritional research shows that the effectiveness of education, even a one-time education, can be very high [31, 34]. Therefore, the aim of the study was to assess the long-term effect of one-time nutrition education among children in early school age. This effect was studied by a developed nutritional knowledge questionnaire after the analysis of nutritional content in children's' textbooks.

\section{MATERIAL AND METHODS}

\section{Participants}

The study was carried out on early school-aged children of a public primary school in Warsaw. The studied group was recruited using a procedure of purposive sampling. Parental written informed consent was obtained for the participation of their children. In total 147 children of early school-age 
(1st-, 2nd- and 3rd-grade classes of primary school) were initially recruited (Figure 1). The inclusion criteria were as follows: headmaster's, class teachers' and children parents' written informed consent. The exclusion criteria were as follows: no parental written consent, as well as reading and spelling difficulties (1st-grade classes). In total 91 participants met the criteria. Due to non-participation in all stages of the study, 15 participants were excluded from the analysis. Finally, the study included 76 children. The number of children participating in the study differed at each of the three stages depending on children's presence as well as written informed consent possession.

\section{Nutritional knowledge assessment}

Nutritional knowledge was measured three times: before the nutritional education (at the baseline, S1 - first stage of the study), immediately after the nutritional education (S2 - second stage of the study), to measure the short-term effect of the education, and six months after the nutritional education (S3 - third stage of the study), to measure the long-term effect of the education (Figure 1). The main study was preceded by a pilot study (in October 2018), in which the understandability and accuracy of the questions were verified. As a result, the final version of the questionnaire was created and used in the main study. At each stage of the study, nutritional knowledge data was collected using a proprietary, self-administrated questionnaire, completed by the participants at school. The questionnaire consisted of a total of 14 items. Three types of questions were used: closed-ended, true-false and ranking questions.

Every closed-ended question had three possible answers, from which only one was always correct (Q1-5, Q7-11; Table 1). Each of the 10 closed-ended questions was scored with 1 point if the chosen answer was correct or 0 points in case of 'I don't know' answer, wrong answers or missing data.

The questionnaire also contained one true-false question with 5 sentences which were scored with 1 point if the answer in the sentence was correct and 0 points if the answer was incorrect or in case of missing data (Q12; Table 1). The questionnaire also included one question with four items, which demanded a selection of a better cereal product from the given couples (Q6; Table 1). This type of questions was scored as follows: 0.5 points for each good choice or 0 points in case of each wrong answer or missing data.

The selection of products which should or should not be a part of a proper meal was also demanded in a question, where various products were shown on pictures and children were asked to choose which products are not recommended and to tick them. It was possible to get 0.5 points for ticking each of the inadvisable products (Q13; Table 1).

The last question was the ranking question, in which the respondents were asked to - using the

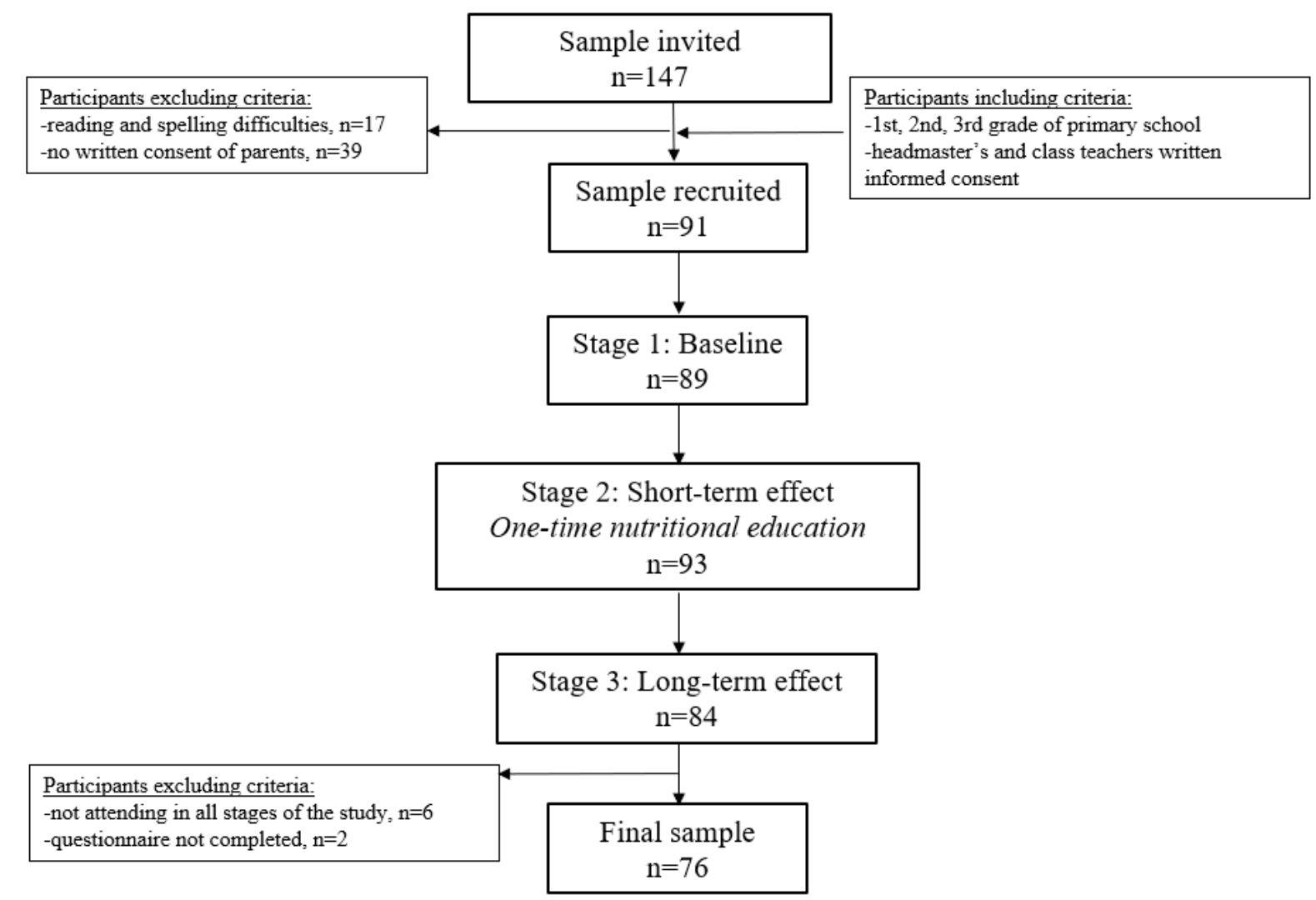

Figure 1. Study design and sample collection 
Table 1. Questions and answers included in questionnaire

\begin{tabular}{|c|c|}
\hline Questions & Answers \\
\hline 1. Is physical activity (sport, exercises) important? & $\begin{array}{l}\text { Yes, because it improves condition and prevents obesity; } \\
\text { Yes, because doing sports allows us to eat more sweets; } \\
\text { No, because physical activity causes tiredness }\end{array}$ \\
\hline 2. Are there any screen time limits? & $<2 \mathrm{~h} / \mathrm{d} ; 4 \mathrm{~h} / \mathrm{d}$ and more; There are no limits \\
\hline 3. Does adequate nutrition affect human health? & $\begin{array}{l}\text { It has no effect on our health; It does not matter - we eat } \\
\text { because we are hungry; It affects our health, strength and } \\
\text { ability to learn }\end{array}$ \\
\hline $\begin{array}{l}\text { 4. Why is it worth to eat varicoloured vegetables and } \\
\text { fruit? }\end{array}$ & $\begin{array}{l}\text { Because they look well together; Because they provide } \\
\text { various ingredients; Colours do not matter }\end{array}$ \\
\hline 5. What should be the main source of fats in a diet? & $\begin{array}{l}\text { Vegetables and fruit; Fish, nuts, plant-based oils; Grain } \\
\text { products and dairy products }\end{array}$ \\
\hline $\begin{array}{l}\text { 6. From each couple choose the product which is more } \\
\text { beneficial for your health }\end{array}$ & $\begin{array}{l}\text { Wheat bread or wheat-rye bread with grains; Kaiser roll } \\
\text { or graham roll; Buckwheat or white rice; Oat flakes or } \\
\text { chocolate flakes }\end{array}$ \\
\hline $\begin{array}{l}\text { 7. Why are milk and milk products needed for proper } \\
\text { human development? }\end{array}$ & $\begin{array}{l}\text { Because they contain iron, which builds blood cells; } \\
\text { Because they contain calcium and vitamin D, which build } \\
\text { our bones and teeth; Because they contain vitamin C, } \\
\text { which empowers immunity }\end{array}$ \\
\hline $\begin{array}{l}\text { 8. Why is it worth to eat dairy products } \\
\text { (e.g. kefir, cheese)? }\end{array}$ & $\begin{array}{l}\text { Because they are a source of fiber; Because they are a } \\
\text { source of 'good bacteria'; Because they contain vitamin } \\
\text { C, which empowers immunity }\end{array}$ \\
\hline $\begin{array}{l}\text { 9. Why is it better to eat wholemeal bread, groats and oat } \\
\text { flakes instead of Kaiser rolls, white rice and chocolate } \\
\text { flakes? }\end{array}$ & $\begin{array}{l}\text { They are more colourful; They contain calcium, which } \\
\text { build bones and teeth; They contain more necessary } \\
\text { ingredients (e.g. fiber and vitamins) }\end{array}$ \\
\hline 10. What can drinking too little water cause? & $\begin{array}{l}\text { Hiccups; Decreased disease resistance; Tiredness during } \\
\text { lessons and difficulty concentrating }\end{array}$ \\
\hline $\begin{array}{l}\text { 11. Should eating sweets and drinking sweet beverages be } \\
\text { limited? }\end{array}$ & $\begin{array}{l}\text { No, because they are tasty; Yes, because parents are } \\
\text { saying that they should be limited; Yes, because in excess } \\
\text { they can cause tooth decay or excess weight }\end{array}$ \\
\hline 12. Choose true sentences & $\begin{array}{l}6 \text { glasses of water should be drunk daily; More fruits than } \\
\text { vegetables should be eaten daily; } 3-4 \text { glasses of milk or } \\
\text { dairy drinks should be drunk daily; It is better to eat a bar } \\
\text { than fruit; Every child should be physically active for at } \\
\text { least } 60 \text { minutes every day }\end{array}$ \\
\hline $\begin{array}{l}\text { 13. Choose those products which should not be a part of } \\
\text { proper meals }\end{array}$ & $\begin{array}{l}\text { Bar; Donut; Fruit juice; Salty sticks; Chips; Pizza; Crisps; } \\
\text { Hamburger }\end{array}$ \\
\hline $\begin{array}{l}\text { 14. Rank the following products from the lowest to the } \\
\text { highest amount of sugar }\end{array}$ & $\begin{array}{l}\text { 1-Tomato juice, 3-Flavoured yoghurt, 2-Banana, } \\
\text { 4-Flavoured water }\end{array}$ \\
\hline
\end{tabular}

numbers from 1 to 4 - rank the products from the ones with the lowest to the ones with the highest amount of sugar. It was possible to get 1 point, if two products were ranked correctly, 2 points if four products were ranked correctly or 0 points in case of ranking 1 or 0 products correctly or in case of missing data (Q14; Table 1).

The points were summed up for each respondent, the maximum was 23 points. Based on number of obtained points, the respondents were divided into five nutritional knowledge levels, labelled as follows: very poor (0-4.5 points), poor (4.6-9.2 points), average (9.3-13.8 points), good (13.9-18.4 points), very good (18.5-23 points) (Table 2 ).
Table 2. Nutritional knowledge categories

\begin{tabular}{|c|c|}
\hline $\begin{array}{c}\text { Nutritional knowledge } \\
\text { categories }\end{array}$ & $(\%$ range (points) $)$ \\
\hline Very poor & $0-20(0-4.5)$ \\
Poor & $21-40(4.6-9.2)$ \\
Average & $41-60(9.3-13.8)$ \\
Good & $61-80(13.9-18.4)$ \\
Very good & $81-100(18.5-23)$ \\
\hline
\end{tabular}

\section{One-time nutritional education}

In the term of November and December 2018 a one-time nutritional education program lasting two hours in each class was implemented. The classes were conducted in the form of talks and exercises 
supporting children's (both individual and group) involvement (discussion as well as guesswork and singing a song about vegetables and fruits). The topics of the classes corresponded to the questions included in the questionnaire. The core components of the education included relaying knowledge of: the importance of healthy eating habits, hydration and physical activity on health, nutritional value of food products, sources of individual nutrients and screen time limits. The classes also included culinary workshops, in which a meal (cottage cheese and varicoloured pepper sandwiches) was prepared together. The aim of the culinary workshops was to show how to prepare a healthy, colourful and tasty meal covering the dietary guidelines. During the classes, the computer-based display responding to the research objectives was used.

\section{Statistical analysis}

To compare the frequency of possible answers selection at the three stages of the study, as well as to check the differences by gender and school class for the sum of obtained points in each stage of the study the Chi-square test was applied. Q-Cochran test was used to compare the frequency of choosing the correct answers in individual questions, over three stages of the study and McNemar's Chi ${ }^{2}$ test was used to compare the frequency of choosing the correct answers in individual questions between the two stages of the study.

For quantitative variables, the differences between the three stages were compared using the KruskalWallis test (sum of obtained points and categories of nutritional knowledge levels). The significance level of $p<0.05$ was used. The following software was used: Statistica 13.0.

\section{RESULTS}

\section{Characteristics of the studied group}

The total number of children who participated in the study was 76 with 46 girls (61\%) and 30 boys (39\%) (Table 3). The mean age of the respondents was 8.4 \pm 1.1 years, with the age ranging from 7 to 10 years; $47 \%$ of the respondents were second-grade children, and $53 \%$ were third-grade children. Initial nutritional knowledge was assessed at an average of 18.1 points $(79 \%)$ for the group, 18.5 points $(80 \%)$ in girls, and 17.4 points $(76 \%)$ in boys.

Analysis of the nutritional content of textbooks, used by the surveyed children

Second-grade children were following an educational program according to the School Friends (Szkolni Przyjaciele) textbook, in which they have hardly ever encountered any nutritional content before a one-time nutritional education. According to the nutritional textbooks content, over time between the second and the third stage of the study, a second-grade child should: understand the food-pyramid nutritional guidelines, know that eating varicoloured vegetables and fruits carries intake of numerous nutrients, and know some of the obesity causes.

Third-grade children were following an educational program according to the New Hunters (Nowi Tropiciele) textbook in the first grade and in the second grade, and the Our school (Nasza szkota) textbook - in third grade. In connection with the above, before the nutritional education, a third-grade student should know: which products could be a part of a healthy meal, the importance of nutrition for health, the nutritional value of various food groups and the importance of eating breakfast as well as how to prepare a healthy breakfast. After the time between the second and the third stage of the study, a thirdgrade student should know that the main role of dairy products is to build strong bones and teeth, because of the high calcium and vitamin D content.

\section{Nutritional knowledge assessment}

While analysing the mean nutrition knowledge score, it was stated that the results differed throughout the study $(\mathrm{p}<0.001 ; \quad$ Kruskal-Wallis test $)$. The respondents gained on average: 18.1/23 (79\%) points at the S1, 21.1/23 (92\%) points at the S2 and 19.7/23 (86\%) points at the S3 (Table 4). At the S1, $47 \%$ of

Table 3. Characteristics of the study group

\begin{tabular}{|c|c|c|c|}
\hline \multirow[t]{2}{*}{ Variables } & $\begin{array}{c}\text { Total sample } \\
n=76(100 \%)\end{array}$ & $\begin{aligned} & \text { Girls } \\
\mathrm{n}= & 46(61 \%)\end{aligned}$ & $\begin{array}{c}\text { Boys } \\
n=30(39 \%)\end{array}$ \\
\hline & Mean $\pm \mathrm{SD}^{*}$ & Mean \pm SD & Mean \pm SD \\
\hline Age & $\begin{array}{c}8.4 \pm 1,1 \\
(7.3-9.8)^{* *}\end{array}$ & $\begin{array}{l}8.4 \pm 0,5 \\
(7.6-9.8)\end{array}$ & $\begin{array}{l}8.3 \pm 0.4 \\
(7.3-9.1)\end{array}$ \\
\hline $\begin{array}{c}\text { Class: } \\
\text { Second grade } \\
\text { Third grade }\end{array}$ & $\begin{array}{l}36(47 \%) \\
40(53 \%)\end{array}$ & $\begin{array}{l}24(52 \%) \\
22(48 \%)\end{array}$ & $\begin{array}{l}12(40 \%) \\
18(60 \%)\end{array}$ \\
\hline NK initial & $79 \%$ & $80 \%$ & $76 \%$ \\
\hline
\end{tabular}

*-standard deviation, **-range; NK -nutritional knowledge 
the respondents had a very good level of nutritional knowledge, while $49 \%$ of the respondents had a good level of nutritional knowledge. The proportion of the respondents who had a very good level of nutritional knowledge at the S2 was higher than at the S3. Non respondent obtained as few points as to assess its level of nutritional knowledge as low or insufficient.

\section{Detailed nutritional knowledge assessment}

The mean nutrition knowledge score differed throughout the study (Table 5). Following the education (comparing the S1 and the S2), the level of NK increased significantly of these topics: better choice for the couple of Kaiser roll and Graham roll as well as buckwheat and white rice, fermented milk products' function in human body, adverse health effect of drinking too little water, as well as daily water requirements, estimating sugar content in food and recommendations on physical activity $(\mathrm{p}<0.001$ for each question) (Table 5).

At each stage of the study only almost half of the respondents knew that good sources of fat are fish, nuts, and plant-based oils, but knowledge of this topic did not change significantly. The majority of the respondents knew, even at the baseline, the importance of healthy eating habits and physical activity, screen time limits, advantages of eating varicoloured vegetables and fruits, and which product from the

Table 4. Distribution of nutritional knowledge levels by stages of the study

\begin{tabular}{|c|c|c|c|c|}
\hline \multirow{2}{*}{ Nutritional knowledge } & \multicolumn{3}{|c|}{$\%$ of respondents } & \multirow{2}{*}{$\mathrm{p}^{*}$} \\
\hline & Stage 1 & Stage 2 & Stage 3 & \\
\hline $\begin{array}{l}\text { Categories } \\
\text { Very poor } \\
\text { Poor } \\
\text { Average } \\
\text { Good } \\
\text { Very good } \\
\end{array}$ & $\begin{array}{c}0 \\
0 \\
4 \\
49 \\
47\end{array}$ & $\begin{array}{c}0 \\
0 \\
0 \\
9 \\
91\end{array}$ & $\begin{array}{c}0 \\
0 \\
0 \\
26 \\
74\end{array}$ & $<0.001$ \\
\hline \multirow[b]{2}{*}{ Obtained points } & & nean $(\%$ & & \multirow[b]{2}{*}{$<0.001$} \\
\hline & $\begin{array}{c}18.1 \\
(79 \%)\end{array}$ & $\begin{array}{c}21.1 \\
(92 \%)\end{array}$ & $\begin{array}{c}19.7 \\
(86 \%)\end{array}$ & \\
\hline
\end{tabular}

*statistically significant (Kruskal-Wallis test); *p<0.05

Table 5. The percentage of correct answers provided by the respondents to questions

\begin{tabular}{|c|c|c|c|c|c|c|c|}
\hline Question & Stage 1 & Stage 2 & Stage 3 & $\mathrm{p}^{1}$ & $\mathrm{p}^{2}$ & $\mathrm{p}^{3}$ & $\mathrm{p}^{*}$ \\
\hline 1. Importance of physical activity & 97 & 99 & 99 & \multirow{5}{*}{ ns } & \multirow{5}{*}{ ns } & \multirow{5}{*}{ ns } & \multirow{5}{*}{ ns } \\
\hline 2. Screen time limits & 95 & 93 & 95 & & & & \\
\hline 3. Adequate nutrition impact on human health & 99 & 95 & 99 & & & & \\
\hline 4. Worth to eat varicoloured vegetables and fruit & 92 & 95 & 95 & & & & \\
\hline 5. The main source of fats in a diet & 55 & 58 & 50 & & & & \\
\hline \multicolumn{8}{|l|}{ 6. Products more beneficial for health } \\
\hline a. Wheat-rye bread with grains & 92 & 95 & 96 & ns & \multirow{4}{*}{ ns } & \multirow{4}{*}{ ns } & ns \\
\hline b. Graham roll & 88 & 97 & 92 & 0.023 & & & 0.004 \\
\hline c. Buckwheat & 83 & 96 & 89 & 0.027 & & & 0.038 \\
\hline d. Oat flakes & 100 & 100 & 100 & ns & & & - \\
\hline 7. Role of milk and milk products & 71 & 79 & 84 & ns & 0.044 & ns & ns \\
\hline 8. Worth to eat dairy products (kefir, cheese) & 20 & 68 & 33 & $<0.001$ & ns & $<0.001$ & $<0.001$ \\
\hline $\begin{array}{l}\text { 9. Whole grain products as better option than } \\
\text { non-whole products }\end{array}$ & 80 & 79 & 87 & ns & ns & ns & ns \\
\hline 10. Too little water effect & 58 & 96 & 68 & $<0.001$ & ns & $<0.001$ & $<0.001$ \\
\hline 11. Sweets and sweet beverages limitation & 87 & 95 & 95 & 0.004 & ns & $<0.001$ & ns \\
\hline \multicolumn{8}{|l|}{ 12. Choose true sentences } \\
\hline a. 5-6 glasses of water should be drunk daily. & 72 & 99 & 95 & $<0.001$ & $<0.001$ & ns & $<0.001$ \\
\hline $\begin{array}{l}\text { b. More fruits than vegetables should be eaten } \\
\text { daily. }\end{array}$ & 81 & 91 & 89 & ns & ns & ns & ns \\
\hline
\end{tabular}




\begin{tabular}{|c|c|c|c|c|c|c|c|}
\hline $\begin{array}{l}\text { c. } 3-4 \text { glasses of milk or dairy drinks should } \\
\text { be drunk daily. }\end{array}$ & 73 & 92 & 84 & 0.005 & ns & ns & 0.008 \\
\hline d. It is better to eat a bar than fruit. & 96 & 100 & 99 & ns & $\mathrm{ns}$ & ns & $\mathrm{ns}$ \\
\hline $\begin{array}{l}\text { e. Every child should be physically active for } \\
\text { at least } 60 \text { minutes every day. }\end{array}$ & 80 & 99 & 97 & $<0.001$ & $<0.001$ & ns & $<0.001$ \\
\hline \multicolumn{8}{|l|}{$\begin{array}{l}\text { 13. Choose those products which shouldn't be } \\
\text { part of proper meals }\end{array}$} \\
\hline a. Bar & 97 & 100 & 100 & \multirow{8}{*}{ ns } & \multirow{8}{*}{ ns } & \multirow{8}{*}{ ns } & \multirow{8}{*}{ ns } \\
\hline b. Donut & 99 & 99 & 100 & & & & \\
\hline c. Fruit juice & 80 & 87 & 89 & & & & \\
\hline d. Salty sticks & 93 & 93 & 96 & & & & \\
\hline e. Chips & 99 & 100 & 100 & & & & \\
\hline f. Pizza & 96 & 97 & 100 & & & & \\
\hline g. Crisps & 96 & 97 & 99 & & & & \\
\hline h. Hamburger & 96 & 99 & 99 & & & & \\
\hline $\begin{array}{l}\text { 14. Ranking products from the lowest to the } \\
\text { highest amount of sugar }\end{array}$ & 25 & 92 & 34 & 0.004 & $\mathrm{~ns}$ & $<0.001$ & $<0.001$ \\
\hline
\end{tabular}

${ }^{*} \mathrm{p}<0.05$ for the Q-Cochran test; $\mathrm{p}^{1-}$ differences between the $\mathrm{S} 1$ and the S2 for the Chi ${ }^{2}$ McNemary test, $\mathrm{p}^{2-}$ differences between the $\mathrm{S} 1$ and the $\mathrm{S} 3$ for the Chi ${ }^{2}$ McNemary test, $\mathrm{p}^{3-}$ differences between the $\mathrm{S} 2$ and the $\mathrm{S} 3$ for the Chi ${ }^{2}$ McNemary test; ns- not statistically significant

given couple of cereal products is healthier (wheatrye bread with grains and wheat bread, oat flakes, and chocolate flakes as well as fruit or a bar). Moreover, most of the surveyed children classified correctly bars, donuts, hamburgers, chips, crisps, salt sticks, and pizza to the group of items that should not be part of healthy meals. In these topics, nutritional knowledge did not change significantly after education (Table 5). A great majority of children at each stage of the study knew that eating sweets and drinking sweet beverages in excess should be limited, because of the greater probability of decay and overweight. Furthermore, at each stage of the study, almost a majority of respondents recognized healthy and unhealthy products, which were set on the pictures. For most respondents of the S1 $(75 \%)$ and S3 (66\%) the task of ranking products (tomato juice, flavoured cheese, banana, flavoured water) by increasing sugar content was too difficult. Only at S2 majority of children coped with this. NK in this topic differed significantly between all stages of the study ( $<<0.001$; Q-Cochran test).

\section{DISCUSSION}

At baseline, general nutritional knowledge, assessed by the implemented questionnaire was good ( $49 \%$ of respondents) or very good $(47 \%$ of respondents) in this group. Immediately after the nutritional education the percentage of children, whose level of nutritional knowledge was assessed as very good doubled. Finally, the nutritional knowledge of $74 \%$ of pupils was classified as very good, which confirmed the effectiveness of the multi-comprehensive one-time nutritional education (lessons with culinary workshops). The majority of the study group had knowledge of healthy lifestyle determinants (physical activity, screen time, and adequate nutrition). Taking into account specific content of nutritional knowledge, between baseline and the final stage, an increase of knowledge of the role of milk, milk products requirements as well as daily water requirements, the effects of drinking too little water, and recommendations on one-hour physical activity per day, was observed. Also, pupils recognized the content of sugar in the examples of food products better, however, only $34 \%$ of them coped with this task after six months. A low percentage of children knew the role of fermented milk drinks, both at the baseline (20\%) and in the end line (33\%) of this study. Moreover, the nutritional education did not change nutritional knowledge concerning fats, about $50 \%$ of pupils were able to classify the nuts, fish, and plant-based oils as fat sources in the diet.

Our results showed that a one-time program can be effective in increasing nutritional knowledge in children. It is consistent with Grajek and Wanat results [10]. The authors found that, after a one-time meeting with dieticians, awareness of recommended servings, according to the Food Pyramid, increased in the group of 4-6 grade children. Similarly, in the group of 164 adolescent girls from India the level of knowledge significantly improved after a one-time nutritional education using slides, charts and folders [26]. Unfortunately, there is very limited published research focusing on improving children's nutrition knowledge, attitudes and behaviours by a one-time nutritional education, while there is a lot of previous studies which indicated beneficial effects of long-term nutrition 
education in the group of children and adolescents [12, $18,19,35]$. For instance, in the study ABC Healthy Eating Program, with participation of 11-12 years-old children, who took part in education program with lasted 15 hours, it was observed that after nutritional education (including nutrition, dietary, sensoryconsumer, hygiene and culinary topics) children from the educational group had a significantly higher increase in nutrition knowledge score than the control group [12, 33]. Even more optimistic, another study of 160 12-year-olds confirmed that nutritional education can also influence children's nutritional behaviours. Comparing the pre-test and post-test, an increase in the frequency of consumption of the breakfasts, milk and its products, fish and fish products and vegetables was observed after 8 hours of nutritional education [19]. In another study in a group of younger children (4-7 years), after classes in the nutrition and physical activity of children and their mothers, the variety of food and fruit and vegetable consumption, habitual drinking of water and the quality score of packaged lunches increased, and the consumption of sweet drinks decreased [18].

Our findings confirmed that even though children know the importance of physical activity, screen time limits, as well as the importance of adequate nutrition in maintaining human health, much more important, is implementing that into practice which is not common in both groups of children and adults. In the study with the participation of 884 adolescents from schools from Upper Silesia (Poland), huge discrepancies were observed between nutrition knowledge and its practical application of it in daily life, especially in the frequency of fish and vegetable consumption as well as a proper number of meals [30]. Similarly, among high school children, it was found that despite the level of nutritional knowledge was assessed as high, in daily life participants did not follow the guidelines of adequate nutrition [39]. It is also worth noticing that only a small percentage of 11-15 years-old children and adolescents from Poland were moderate physically active, both moderate $(17.2 \%)$, at the recommended level as well as most of the surveyed children $(79 \%)$ spent more than 2 hours on watching TV or movies on the computer, according to the Health Behaviour of School-age Children (HBSC) report [21]. The above data confirmed the need for further research focused both on children's nutritional knowledge and nutritional behaviours.

In the present study, one-time nutritional education increased the knowledge of the role of milk and milk products between the first and third stages of this study. We observed also an increase between the second and third stages of the study in pupils of grade 3 (75\% of respondents and $90 \%$ of respondents knew the role of milk products, respectively; data not shown). It may be linked with the content of textbooks in third-grades, where dairy products were mentioned, in the context of the human skeleton (information on the beneficial effects of milk and dairy products the proper structure of bones and teeth; it was also specified that this is due to the presence of calcium and vitamin D). It could be the explanation of the improvement between the second and third stage of the study. However, knowledge of the role of fermented milk products was not enough, and nutritional education in this topic caused only short-term effect.

In our study over $20 \%$ of children at the baseline were not aware of how much milk products should be eaten every day, as well as did not know the water requirements. The level of knowledge in this field slightly increased after nutritional education. Probably, for children who answered incorrectly, the answer 3-4 cups a day of milk products as well as 5-6 glasses of water could seem like a huge amount, while it might have been better to present it as pictures of portions, for a better understanding of the question. In contrast to the present study, at baseline much less adolescents from Poland (1/4 of them) knew how much milk and milk-based products should be eaten daily, while after nutritional education (lecture and presentation) $80 \%$ of adolescents were aware of that [34]. The above questions checked if children understand the dietary recommendations. In previous studies it was observed that understanding and legibility of recommendations in the form of Food Pyramid is insufficient, even in older age groups $[9,38]$. Moreover, it was found that children aged 10-11 years were rather poorly recognizing the portion size [9]. In another study with primary school and junior high school pupils' participation, the poorest awareness was also observed in the field of food groups [23]. Therefore, based on previous studies and own findings, it seems necessary to constantly adapt the forms of conveying nutritional recommendations to children, for better understanding and, as a result, using them in everyday life.

\section{CONCLUSIONS}

This study shows that even a one-time nutritional education, including culinary workshops and various methods of activating children (discussion, guesswork, singing), can give measurable and long-lasting effects, in the form of improvement of children's nutritional knowledge level. The subsequent activities at the same educational stage should broaden issues such as: composing appropriate meals, eating breakfast, nutritional value of dairy products, the role of water in children's health, sources of sugar and fat in the diet. School health promotion activities, including nutritional education, should be more attractive to the young audience and focus on improving nutritional 
literacy. Further research should focus on the effectiveness of nutrition education, both single and multiple, especially when combined with nutritional changes (the ability to apply knowledge in practice).

\section{Conflict of interests}

The authors declare no conflict of interest.

\section{REFERENCES}

1. Bates L.C., Zieff G., Stanford K., Moore J.B., Kerr, Z.Y., Hanson E.D., Barone Gibbs B., Kline C.E., Stoner L.: COVID-19 Impact on Behaviors across the 24-Hour Day in Children and Adolescents: Physical Activity, Sedentary Behavior, and Sleep. Children 2020; 7(9): 138, doi: 10.3390/children7090138.

2. Cotton W., Dudley D., Peralta, L., Werkhoven T.: The effect of teacher-delivered nutrition education programs on elementary-aged students: An updated systematic review and meta-analysis. Prev Med Rep 2020; 20: 101178, doi: 10.1016/j.pmedr.2020.101178.

3. De Onis M., Blössner M., Borghi E.: Global prevalence and trends of overweight and obesity among preschool children. Am J Clin Nutr 2010; 92(5): 1257-1264.

4. De Onis M., Onyango A.W., Borghi E., Siyam A., Nishida C., Siekmann, J.: Development of a WHO growth reference for school-aged children and adolescents. Bull World Health Organ 2007, 85(9): 660-667.

5. Devine A., Lawlis T:: Nutrition and Vulnerable Groups. Nutrients 2019; 11(5): 1066, doi: 10.3390/nu11051066.

6. Di Cesare M., Sorić M., Bovet P., Miranda J.J., Bhutta Z., Stevens G.A., Laxmaiah A., Kengne A.P., Bentham, $J$ : : The epidemiological burden of obesity in childhood: a worldwide epidemic requiring urgent action. BMC Med 2019; 17: 212, doi: 10.1186/s12916-019-1449-8.

7. European Childhood Obesity Surveillance Initiative (COSI 2015-2017). Available: http://www.euro.who. int/en/who-european-childhood-obesity-surveillanceinitiative-cosi. Accessed: 10.10.2020.

8. Figurska-Ciura D., Bartnik J., Bronkowska M., Biernat $J .:$ Jakościowa i ilościowa ocena wpływu edukacji żywieniowej na spożycie wybranych składników pokarmowych oraz ocena wiedzy żywieniowej młodych piłkarzy [Qualitative and quantitative assessment of the impact of nutritional education on the intake of selected nutrients and evaluation of nutritional knowledge of young football players]. Probl Hig Epidemiol 2014; 95(2): 471-476 (in Polish).

9. Górnicka M., Wiszniewska M., Wojtaś M., Wawrzyniak A., Kanigowska A.: Assessing schoolchildren's ability to make proper use of a food and nutrition pyramid. Rocz Panstw Zakl Hig 2013; 64(2): 149-154.

10. Grajek M., Wanat G.: Skuteczność przekazu zdrowotnego na przykładzie edukacji żywieniowej uczniów z użyciem piramidy żywieniowej [The effectiveness of health education analysed on the basis of teaching students proper nutrition using the food pyramid concept]. J Ecol Health 2013; 17(3): 153-157 (in Polish).
11. Guo S.S., Wu W., Chumlea W.C., Roche A.F.: Predicting overweight and obesity in adulthood from body mass index values in childhood and adolescence. Am J Clin Nutr 2002; 76(3): 653-658.

12. HamułkaJ., WadołowskaL., HoffmannM., Kowalkowska J., Gutkowska K.: Effect of an Education Program on Nutrition Knowledge, Attitudes toward Nutrition, Diet Quality, Lifestyle, and Body Composition in Polish Teenagers. The ABC of Healthy Eating Project: Design, Protocol, and Methodology. Nutrients 2018; 10(10): 1439, doi:10.3390/nu10101439.

13. HanhN.T.H.,LeT.,DaoD.T.A., Tao Y., ChuD.-T.:Childhood obesity is a high-risk factor for hypertriglyceridemia: A case-control study in Vietnam. Osong Public Health Res Perspect 2017; 8(2): 138-146.

14. Huizar M.I., Arena R., Laddu D.R.: "Covibesity," a new pandemic. Obes Med 2020, 19: 100282, doi:10.1016/j. obmed.2020.100282.

15. I know what I eat [Wiem co jem]. Available: https:// wiemcojem.um.warszawa.pl/. Accessed 07.10.2020 (in Polish).

16.Jeruszka-Bielak M., Kołtajtis-Dołowy A.: Możliwości zdobywania wiedzy żywieniowej a efektywność jej przekazywania w placówkach oświatowych w Polsce [Opportunities for gaining nutritional knowledge and the effectivenes of sharing knowledge in educational establishments in Poland]. In: Wolska-Adamczyk A., Współczesne kierunki działań prozdrowotnych [Contemporary directions of pro-health activites]. Warsaw, WSIiZ, 2015 (in Polish).

17. Jongenelis M., Pettigrew S., Chapman K., Miller C.: Factors influencing children's consumption of unhealthy foods. Eur J Public Health 2016; 26(supl. 1): 174.061, doi: 10.1093/eurpub/ckw174.061.

18. Kaufman-Shriqui V., Fraser D., Friger M., Geva D., Bilenko N., Vardi H., Elhadad N., Mor K., Feine Z., Shahar D.R.: Effect of a School-Based Intervention on Nutritional Knowledge and Habits of LowSocioeconomic School Children in Israel: A ClusterRandomized Controlled Trial. Nutrients 2016; 8(4): 234, doi:10.3390/nu8040234.

19. Kwiatkowska M., Wawrzyniak A.: Edukacja żywieniowa jako element poprawiający zachowania żywieniowe oraz wybrane parametry antropometryczne $\mathrm{w}$ grupie dzieci w wieku 12 lat [Nutritional education as an element improving nutritional behavior and selected anthropometric parameters in the group of children aged 12 years]. Piel Zdr Publ 2019; 9(3): 173-182 (in Polish).

20.Mattioli A.V., Pinti M., Farinetti A., Nasi M.: Obesity risk during collective quarantine for the COVID-19 epidemic. Obes Med 2020; 20:100263, doi:10.1016/j. obmed.2020.100263.

21.Mazur, J., Małkowska-Szkutnik, A. et al.: Zdrowie uczniów w 2018 roku na tle nowego modelu badań HBSC [Health of students in 2018 against the background of the new HBSC model]. Warsaw, IMiD, 2018 (in Polish). 22.Murimi M.W., Kanyi M., Mupfudze T., Amin M.R., Mbogori T., Aldubayan K.: Factors Influencing Efficacy 
of Nutrition Education Interventions: A Systematic Review. J Nutr Educ Behav 2017; 49(2):142-165.

23. Naeeni M.M., Jafari S., Fouladgar, M., Heidari K., Farajzadegan Z., Fakhri M., Karami P., Omidi R.: Nutritional Knowledge, Practice, and Dietary Habits among school Children and Adolescents. Int J Prev Med 2014; 5(supl. 2): 171-178.

24.Ng M., Fleming T., Robinson M., Thomson B., Graetz N., Margono C., Mullany E.C., Biryukov S., Abbafati C., Abera S.F. et al.: Global, regional, and national prevalence of overweight and obesity in children and adults during 1980-2013: A systematic analysis for the Global Burden of Disease Study 2013. Lancet 2014; 384(9945): 766-781.

25. Program for schools [Program dla szkół]. Available: https://www.programdlaszkol.org/. Accessed 07.10.2020 (in Polish).

26.Rao R.D., Vijayapushpam T., Subba Rao G.M., Antony G.M., Sarma K.V.R.: Dietary habits and effect of two different educational tools on nutrition knowledge of school going adolescent girls in Hyderabad, India. Eur J Clin Nutr 2007; 61(9): 1081-1085.

27. Sahoo K., Sahoo B., Choudhury A.K., Sofi N.Y., Kumar R., Bhadoria A.S.: Childhood obesity: causes and consequences. J Family Med Prim Care 2015, 4(2): 187-192.

28.Scaglioni S., De Cosmi V., Ciappolino V., Parazzini F., Brambilla P., Agostoni C.: Factors Influencing Children's Eating Behaviours. Nutrients 2018; 10(6): 706, doi:10.3390/nu10060706.

29. Stavridou A., Kapsali E., Panagouli E., Thirios A., Polychronis K., Bacopoulou, F., Psaltopoulou, T., Tsolia, M., Sergentanis, T.N., Tsitsika, A.: Obesity in Children and Adolescents during COVID-19 Pandemic. Children 2021; 8(2): 135, doi:10.3390/children8020135.

30.Szczepańska E., Szeja N., Dudzik I., Kołdon A., Jędzura K., Pochopień E., Oleszko M.: Zachowania żywieniowe i wiedza żywieniowa uczniów wybranych szkół na terenie Górnego Śląska, w zależności od wskaźnika wagowo-wzrostowego BMI [Eating behaviours and nutrition knowledge of students from selected schools of the Upper Silesian region, depending on the Body Mass Index]. Nowa Pediatria 2015; 19(2): 68-75 (in Polish).

31. Ukleja A., Heropolitańska-Janik J., Sińska B., Kunachowicz H., Milewska M.: Ocena wpływu edukacji żywieniowej na poziom wiedzy żywieniowej u dzieci $\mathrm{w}$ wieku szkolnym [Assessment of the nutritional knowledge of children aged 10-14, after a lecture about the principles of rational nutrition]. Zyw Czł Metab 2003; 30(1-2): 428-434(in Polish).

32. Vereecken C., De Pauw A., Van Cauwenbergh S., Maes $L .:$ Development and test-retest reliability of a nutrition knowledge questionnaire for primary-school children. Public Health Nutr 2012; 15(9): 1630-1638.

33. Wadolowska L., Hamułka J., Kowalkowska J., Ulewicz N., Hoffmann M., Górnicka M., Bronkowska M.,
Leszczyńska T., Glibowski P., Korzeniowska-Ginter R.: Changes in Sedentary and Active Lifestyle, Diet Quality and Body Composition Nine Months after an Education Program in Polish Students Aged 11-12 Years: Report from the ABC of Healthy Eating Study. Nutrients 2019; 11(2): 331: doi:10.3390/nu11020331.

34. Wanat G., Stolarczyk A., Grochowska-Niedworok E., Kardas M.: Badania nad edukacją żywieniową i poziomem wiedzy o racjonalnym żywieniu uczniów gimnazjum [Research on nutritional education and level of knowledge on a well-balanced diet of junior high school pupils]. Hygeia Public Health 2011; 46(3): 376-380 (in Polish).

35. Wang D., Stewart D., Chang C., Shi Y.: Effect of a schoolbased nutrition education program on adolescents' nutrition-related knowledge, attitudes and behavior in rural areas of China. Environ Health Prev Med 2015; 20(4): 271-278.

36.Weker, H., Kowalewska-Kantecka, B., Oblacińska, A., Rowicka, G., Tabak, I., Jodkowska, M., Kluba, L., Barańska, M., Dylag, H., Strucińska, M.: Żywienie i aktywność fizyczna dzieci w wieku szkolnym [Nutrition and physical activity of school-age children]. In Weker H., Gronowska-Senger A., O żywieniu i aktywności fizycznej dzieci [About nutrition and physical activity of children]. Warsaw, IMiD, 2015 (in Polish).

37. WHO. Obesity and overweight. Key facts. Available: https://www.who.int/news-room/fact-sheets/detail/ obesity-and-overweight. Accessed 01.10.2020.

38. Wojtaś M., Koltajtis-Dołowy A.: Zachowania żywieniowe wybranej grupy uczniów ostatnich klas szkół ponadgimnazjalnych w Warszawie [Level of knowledge on food and nutrition among groups of pupils of the last class of secondary schools]. Rocz Panstw Zakl Hig 2012; 63(2): 213-217 (in Polish).

39. Wojtyła-Buciora P., Marcinkowski J.T.: Sposób żywienia, zadowolenie $\mathrm{z}$ własnego wyglądu i wyobrażenie o idealnej sylwetce młodzieży licealnej [A diet, satisfaction with physical appearance and a notion of perfect figure according to high-school students]. Probl Hig Epidemiol 2010; 91(2): 227-232 (in Polish).

40. Woynarowska B.: Edukacja zdrowotna w szkole w Polsce. Zmiany w ostatnich dekadach i nowa propozycja [School health education in Poland. Changes in the last decades and a new proposal]. Probl Hig Epidemiol 2008; 89(4): 445-452 (in Polish).

41. Zalewska M., Maciorkowska E.: Rola edukacji żywieniowej w populacji dzieci i młodzieży [Role of nutritional education in the group of children and adolescents]. Med Og Nauk Zdr 2013; 19: 375-378 (in Polish).

Received: 12.03.2021

Accepted: 12.04.2021

Published online first: 04.05.2021

This article is available in Open Access model and licensed under a Creative Commons Attribution-Non Commercial 3.0.Poland License (CC-BY-NC) available at: http://creativecommons.org/licenses/by-nc/3.0/pl/deed.en 